\title{
Distributions and phylogeographic data of rheophilic freshwater fishes provide evidences on the geographic extension of a central-brazilian amazonian palaeoplateau in the area of the present day Pantanal Wetland
}

\author{
Alexandre C. Ribeiro ${ }^{1}$, Rodrigo M. Jacob ${ }^{1}$, Ronnayana R. S. R. Silva ${ }^{2}$, \\ Flávio C. T. Lima ${ }^{3}$, Daniela C. Ferreira ${ }^{1}$, Katiane M. Ferreira ${ }^{1}$, \\ Tatiane C. Mariguela ${ }^{4}$, Luiz H. G.. Pereira ${ }^{4}$ and Claudio Oliveira ${ }^{4}$
}

The analysis of the distribution patterns presented by examples of freshwater fishes restricted to headwater habitat: the anostomid Leporinus octomaculatus, the characins Jubiaba acanthogaster, Oligosarcus perdido, Moenkhausia cosmops, Knodus chapadae, Planaltina sp., the loricariid Hypostomus cochliodon, and the auchenipterid Centromochlus sp. provided evidences of a relatively recent shared history between the highlands of the upper rio Paraguay and adjoining upland drainage basins. Restricted to headwater of the uplands in the upper rio Paraguay and adjoining basins, these species provide biological evidence of the former extension of the central Brazilian plateau before the origin of the Pantanal Wetland. Disjunction took place due to an ecological barrier to these rheophilic taxa represented tectonic subsidence related to the origin of the Pantanal Wetland. Molecular analysis of Jubiaba acanthogaster revealed that the sample from the upper rio Xingu basin are the sister-group of a clade that includes samples from the upper rio Arinos (upper rio Tapajós) plus the upper rio Paraguay basin, supporting the assumption that the origin of the upper rio Paraguay basin causing vicariance between this basin and the upper rio Tapajós is the least vicariant event in the evolutionary history of the group.

A análise do padrão de distribuição apresentado por exemplos de peixes de água doce neotropicais restritos à habitats reofílicos de cabeceira: o anostomídeo Leporinus octomaculatus, os caracídeos Jubiaba acanthogaster, Oligosarcus perdido, Moenkhausia cosmops, Knodus chapadae, Planaltina sp., o loricariídeo Hypostomus cochliodon e o auquenipterídeo Centromochlus sp. fornecem evidências de uma história compartilhada relativamente recente entre as terras altas do alto rio Paraguai e bacias de terras altas vizinhas. Restritas às cabeceiras das áreas altas nas bacias do alto rio Paraguai e bacias vizinhas, estas espécies fornecem evidências biológicas da pretérita extensão do Planalto Central Brasileiro anteriormente a origem tectônica da planície alagável do Pantanal. Disjunções ocorreram devido a barreira ecológica para estes taxons reofílicos representada pela subsidência tectônica associada à origem do Pantanal. A análise molecular de Jupiaba acanthogaster revelou que amostras da bacia do alto rio Xingu consistem no grupo-irmão de um clado mais inclusivo que inclui amostras do alto rio Arinos (alto rio Tapajós) mais o alto rio Paraguai, suportando a suposição de que a origem do alto rio Paraguai causou vicariância entre esta bacia e o alto rio Tapajós no último evento vicariante na história evolutiva do grupo.

Key words: Brazil, Brazilian highlands, Historical biogeography, Paleodrainage, Tectonic evolution.

\footnotetext{
${ }^{1}$ Universidade Federal de Mato Grosso (UFMT), Departamento de Biologia e Zoologia, Instituto de Biociências. Av. Fernando Corrêa da Costa nº 2367, Boa Esperança, 78060-900 Cuiabá, MT, Brazil. alexandrecunharibeiro@gmail.com (ACR).

${ }^{2}$ Instituto Nacional de Pesquisas da Amazônia (INPA), Programa de Pós-Graduação em Biologia de Água Doce e Pesca Interior, Manaus, Brazil.r.rayla@hotmail.com

${ }^{3}$ Universidade Estadual de Campinas, Museu de História Natural Adão José Cardoso, Campinas, São Paulo, Brazil. fctlima@gmail.com ${ }^{4}$ Universidade Estadual Paulista, Departamento de Morfologia, Instituto de Biociências, Botucatu, São Paulo, Brazil. claudio@ibb.unesp.br $(\mathrm{CO})$
} 


\section{Introduction}

The Neotropical freshwater fish fauna is the most speciose on Earth (Schaefer, 1998) and its major biogeographic patterns demonstrate a long evolutionary history that can be traced back to Gondwanaland (Britto et al., 2007). This stupendous evolutionary diversification occurred over tens of millions of years, and over the South American continental arena (Albert \& Reis, 2011).

Since the opening of the Atlantic Ocean in the late Mesozoic, the tectonic evolution of the South American Platform has been driven by the balance of two main antagonistic forces: the ridge push, represented by the spreading of the Atlantic Ocean floor in the divergent margin; and the slab pull, present in the subduction slab of the Nazca Plate beneath the South American Plate in the opposite convergent margin (Riccomini et al., 2004). Reactivation of ancient South American Precambrian and Mesozoic continental rift systems in the Cenozoic has been strongly influenced by these still active forces, and neotectonic activity is still present in all South American geological provinces (Riccomini \& Assumpção, 1999).

Among the set of tectonically imposed landscapes, Andean foreland basins are of major significance in shaping present-day topography and drainage. Foreland basin systems develop as a result of flexural warping of the lithosphere in response to supralithospheric and sublithospheric orogenic wedging (DeCelles \& Giles, 1996). Lithospheric flexure under static loads generates downbending exure proximal to the orogen, which migrates away from the orogen as the load increases (Uba et al., 2006). The Andean foreland basins can be described as sets of "expanding lowlands" into which adjacent uplands become incorporated as the tectonic load advances eastward (Lima \& Ribeiro, 2011). An example of such dynamics is exemplied by the origin of the Pantanal Wetland, a tectonic depression developed due to tectonic reactivations of Precambrian faults along the Trans-brazilian lineament, a major suture zone, up to $350 \mathrm{~km}$ wide in its central part which can be traced from the NE coast of Brazil, through Brazil into Paraguay (Fairhead \& Maus, 2003) (Fig.1) approximately 2.5 MY ago (Soares et al., 1998; Assine, 2004). How does such a dramatic landscape reconfiguration affect freshwater fishes distribution? Is this phenomenon still recognized in the present-day distributional patterns of freshwater fishes of the upper rio Paraguay basin and neighboring areas? As we shall demonstrate, distribution patterns of headwater freshwater fishes have resulted from the tectonic evolution of the upper rio Paraguay river basin and the origin of the Pantanal Wetland in the Cenozoic. We also test the hypothesis that the tectonic origin of the upper rio Paraguay basin corresponds to the most recent vicariant event in the evolutionary history of the area based on the phylogeographic analysis of Jupiaba acanthogaster (Characiformes: Characidae), a species shared and widespread between the upper rio Paraguay and rio Amazonas basin.

\section{Material and Methods}

Species distribution were analyzed and mapped based on material deposited at MZUSP (Museu de Zoologia da Universidade de São Paulo, São Paulo, Brazil), CPUFMT (Coleção de Peixes da Universidade Federal de Mato Grosso, Cuiabá, Brazil), NUPELIA (Núcleo de Pesquisa em Limnologia e Aquicultura, Maringá, Brazil) as well as from reliable published data.

Mapping was carried out using the software Quantum GIS (available at www. qgis.org) in association with geographic data provided by Hearn et al. (2000) and Bizzi et al. (2001).

Molecular analysis includes a total of seventy-three Jupiaba acanthogaster specimens from 15 localities in the upper rios Paraguay, Xingu and Tapajós basins. Jupiaba polylepis was used as outgroup. Voucher tissue samples are deposited at Laboratório de Biologia e Genética de Peixes, Departamento de Morfologia, Instituto de Biociências UNESP, Botucatu, São Paulo, Brazil (Table 1). Total genomic DNA was isolated from scales and muscle tissue of each specimen by using DNeasy Tissue kits (Qiagen) and Phire Animal Tissue Direct PCR kit (Finnzymes), following manufacture's protocol. The partial mitochondrial gene Cytochrome c oxidase subunit I (COI) was amplified by PCR using the primers: Fish F1 5'TCAACCAACCACAAAGACATTGGCAC -3'; Fish R1 5'TAG ACT TCT GGG TGG CCAAAG AAT CA -3' (Ward et al., 2005). Polymerase chain reaction (PCR) and the cycle sequencing reaction were carried out following Pereira et al. (2011). All samples were sequenced on the ABI 3130 Genetic Analyzer (Applied Biosystems) following the instruction manual. All sequences were deposited in GenBank (KC618740-KC618768).

The sequences were analyzed using the software SeqScape ${ }^{\circledR}$ v2.6 (Applied Biosystems) and aligned in the online version of the program MUSCLE (Edgar 2004). Genetic distances among sequences were calculated in Mega 5.04 (Tamura et al., 2011). Maximum parsimony (MP) analyses were conducted with PAUP* 4.0b10 (Swofford, 2003). Heuristic searches were performed with minimally 1000 random addition replicates and TBR branch swapping. All characters were unordered, all character transformations were equally weighted. Clade robustness was assessed using 1000 bootstrap pseudoreplicates (Felsenstein, 1985) with the same parameters as above. RAxML-HPC2 7.2.8 (Stamatakis et al., 2008; Stamatakis \& Pfeiffer, unpublished) using the web page Cipres Science Gateway (Miller et al., 2010) was used for all maximum likelihood (ML) analyses using a mixed partition model with three partitions corresponding to each codon position. Random starting trees were used for each independent ML tree search and all other parameters were set on default values. All ML analyses were conducted under GTR + G since RAxML only applies this model (Stamatakis et al., 2008). Topological robustness was investigated using 1000 bootstrap pseudoreplicates (Felsenstein, 1985). 
Table 1. Voucher specimens and tissue samples of Jupiaba acanthogaster used for phylogeographic analysis.

\begin{tabular}{|c|c|c|c|}
\hline $\begin{array}{c}\text { Voucher } \\
\text { Specimens }\end{array}$ & Coordinate & Localities & Voucher tissue \\
\hline CPUFMT 624 & $13^{\circ} 50^{\prime} 56.9^{\prime \prime} \mathrm{S} / 53^{\circ} 15^{\prime} 22.9^{\prime \prime} \mathrm{W}$ & rio Culuene, upper rio Xingú & LBP 50142-50146; LBP 58240 \\
\hline LBP 1924 & $18^{\circ} 30^{\prime} 38.1^{\prime \prime} \mathrm{S} / 54^{\circ} 46^{\prime} 05.1^{\prime \prime} \mathrm{W}$ & Córrego São Francisco, upper rio Paraguay & LBP 14058 \\
\hline LBP 5790 & $15^{\circ} 19^{\prime} 7.16^{\prime \prime} \mathrm{S} / 56^{\circ} 00^{\prime} 31.8^{\prime \prime} \mathrm{W}$ & rio Cuiabá, upper rio Paraguay & LBP $28212-28214$ \\
\hline LBP 7670 & $15^{\circ} 07.36^{\prime} \mathrm{S} / 55^{\circ} 58.53^{\prime} \mathrm{W}$ & rio Cóxipo-Acu & LBP $36218-36222$ \\
\hline LBP 8512 & $15^{\circ} 19^{\prime} 53.5^{\prime \prime} \mathrm{S} / 57^{\circ} 11^{\prime} 31.1$ ' W & rio Salobra, upper rio Paraguay & LBP 41778; LBP 41781 \\
\hline LBP 10792 & $18^{\circ} 25^{\prime} 24.4^{\prime \prime} \mathrm{S} / 54^{\circ} 50^{\prime} 05.9^{\prime \prime} \mathrm{W}$ & ribeirão dos Veados, upper rio Paraguay & LBP 49905; LBP 49907-49909 \\
\hline CPUFMT 1471 & $15^{\circ} 21^{\prime} 14.99^{\prime \prime} \mathrm{S} / 55^{\circ} 53^{\prime} 35.99^{\prime \prime} \mathrm{W}$ & rio Paciência, upper rio Paraguay & LBP 50147-50151; LBP 58243-58244 \\
\hline CPUFMT 1472 & $14^{\circ} 45^{\prime} 51.99^{\prime \prime} \mathrm{S} / 57^{\circ} 17^{\prime} 5.69^{\prime \prime} \mathrm{W}$ & rio Angelim, upper rio Paraguay & LBP 50152-50156; LBP 58248-58252 \\
\hline CPUFMT 1473 & $15^{\circ} 45^{\prime} 43.99^{\prime \prime} \mathrm{S} / 55^{\circ} 39^{\prime} 16.99^{\prime \prime} \mathrm{W}$ & rio Aricá-Mirim, upper rio Paraguay & LBP 50167- 50171; LBP 58263 \\
\hline CPUFMT 706 & $17^{\circ} 18^{\prime} 37.11^{\prime \prime} \mathrm{S} / 53^{\circ} 32^{\prime} 22.81^{\prime \prime} \mathrm{W}$ & córrego Pinguela, upper rio Paraguay & LBP 50172-50176; LBP 58269-58271 \\
\hline LBP 13572 & $17^{\circ} 55^{\prime} 16.0^{\prime \prime} \mathrm{S} / 57^{\circ} 28^{\prime} 31.6^{\prime \prime} \mathrm{W}$ & Corumbá, upper rio Paraguay & LBP 56393-56394; LBP 56396- 56397 \\
\hline CPUFMT 1474 & $15^{\circ} 39^{\prime} 8.06^{\prime \prime} \mathrm{S} / 57^{\circ} 12^{\prime} 50.12^{\prime \prime} \mathrm{W}$ & Serra Araras, upper rio Paraguay & LBP $58001-58005$ \\
\hline CPUFMT 1475 & $13^{\circ} 45^{\prime} 30.94^{\prime \prime} \mathrm{S} / 56^{\circ} 3^{\prime} 14.45^{\prime \prime} \mathrm{W}$ & rio dos Patos, upper rio Tapajós & LBP 50157-50161; LBP 58253; LBP 58257 \\
\hline CPUFMT 1476 & $13^{\circ} 48^{\prime} 30.36^{\prime \prime} \mathrm{S} / 56^{\circ} 08^{\prime} 38.71^{\prime \prime} \mathrm{W}$ & córrego Piquiri, upper rio Tapajós & LBP 58258-58260; LBP 58262 \\
\hline LBP 8590 & $14^{\circ} 09^{\prime} 14.9^{\prime \prime} \mathrm{S} / 56^{\circ} 05^{\prime} 41.6^{\prime \prime} \mathrm{W}$ & rio Taquari, upper rio Tapajós & LBP 43401 \\
\hline
\end{tabular}

To generate the relative nucleotide composition, number of polymorphic sites, haplotype diversity (h), nucleotide diversity (p), and number of pairwise nucleotide differences among populations, the program ARLEQUIN 3.5.1.2 (Excoffier et al., 2005) was used. To estimate the levels of genetic divergence among groups, the diversity measure FST was calculated using AMOVA (Excoffier et al., 1992) under the parameters of the Tamura \& Nei (1993) nucleotide substitution model. FST estimates were non-parametrically tested $(1,000$ bootstrapped replicates) using the ARLEQUIN 3.0 software and adjusted for simultaneous pairwise comparisons using the sequential Bonferroni procedure (Rice 1989). An haplotypic network was constructed with the program Network 4.5.1.6(FLUXUS TECHNOLOGY LTDA, 2009).

\section{Results}

Leporinus octomaculatus Britski \& Garavello, 1993 was originally described from the upper rio Arinos, a tributary of the rio Tapajós basin. However, this species have been also reported in the upper rio Paraguay basin (Birindelli \& Britski, 2009; A. C. Ribeiro, pers. obs. voucher CPUFMT 973). Despite the absence of a formal phylogenetic analysis of the group, morphological evidences strongly suggest that Leporinus octomaculatus belongs to a monophyletic group that also includes several species from the upland adjacent amazonian drainages (Birindelli \& Britski, 2009). Lima et al. (2007) described Moenkhausia cosmops and also reported its occurrence also in both the upper rios Tapajós and upper Paraguay basins.

Hypostomus cochliodon Kner, 1854 have been revised recently (Armbruster, 2003) and the species is also restricted to running-water habitats along the edges of the upper rio Paraguay basin. Hypostomus from the "cochliodon" group are also typical amazonian representatives.

Oligosarcus perdido Ribeiro, Cavallaro \& Froehlich, 2007 was described from the Serra da Bodoquena Plateau in the southern limit of the upper rio Paraguay basin, and additional material from the upper rio Cuiabá basin revealed a notable disjunct distribution of this species in the upper rio Paraguay basin. This species is more closely related to other species from the upland basins of central Brazil than with $O$. oligolepis, the only know Oligosarcus species from the lower portion of the rio Paraguay basin (Ribeiro, 2007).

Some new records from the upper rio Paraguay basin are also examples of a more closely shared history between the uplands of the upper rio Paraguay with the adjoining upland basins than with the lowland section of the upper rio Paraguay basin. Planaltina sp., recently discovered from rio Sepotuba, a tributary of the upland portion of the upper rio Paraguay basin, has related counterparts only in the upper rio Paraná basin of SE Brazil (Menezes et al., 2003). Additionally, the recently reported occurrence of Centromochlus sp. from the upper rio Itiquira, a left side tributary of the upper rio Paraguay is another evidence, since the genus are typical from Amazon basin and Northern South American drainages. Both records have voucher specimens in CPUFMT (CPUFMT 1463, CPUFMT 1464, and CPUFMT 1465, respectively).

The distributions (Fig. 1) show that, in the case of species occurring also outside the upper rio Paraguay basin, distributions are clearly associated with upland headwaters in both the upper rio Paraguay basin as well as in the adjacent basins, especially the amazonian upper rios Tapajós and Xingu. In case of species restricted to the upper rio Paraguay, distributions are limited to the basin periphery and disjunction are observed in the lowland portion of the upper rio Paraguay (Pantanal Wetland). Species of freshwater fishes restricted to upland headwaters is a recurrent pattern in the Neotropical region (Menezes et al., 2008; Nogueira et al., 2010; Lima \& Ribeiro, 2011). In some cases, upland headwaters of the ancient Brazilian crystalline shield are examples of areas for relict species (Menezes et al., 2008; Lujan \& Armbruster, 2011).

Jupiaba acanthogaster (Eigenmann 1911) is widespread in clear, running-water streams in the upper rios Paraguay, Tapajós and Araguaia-Tocantins drainages (Lima \& Ribeiro, 2011). Jupiaba is a well corroborated monophyletic taxa 


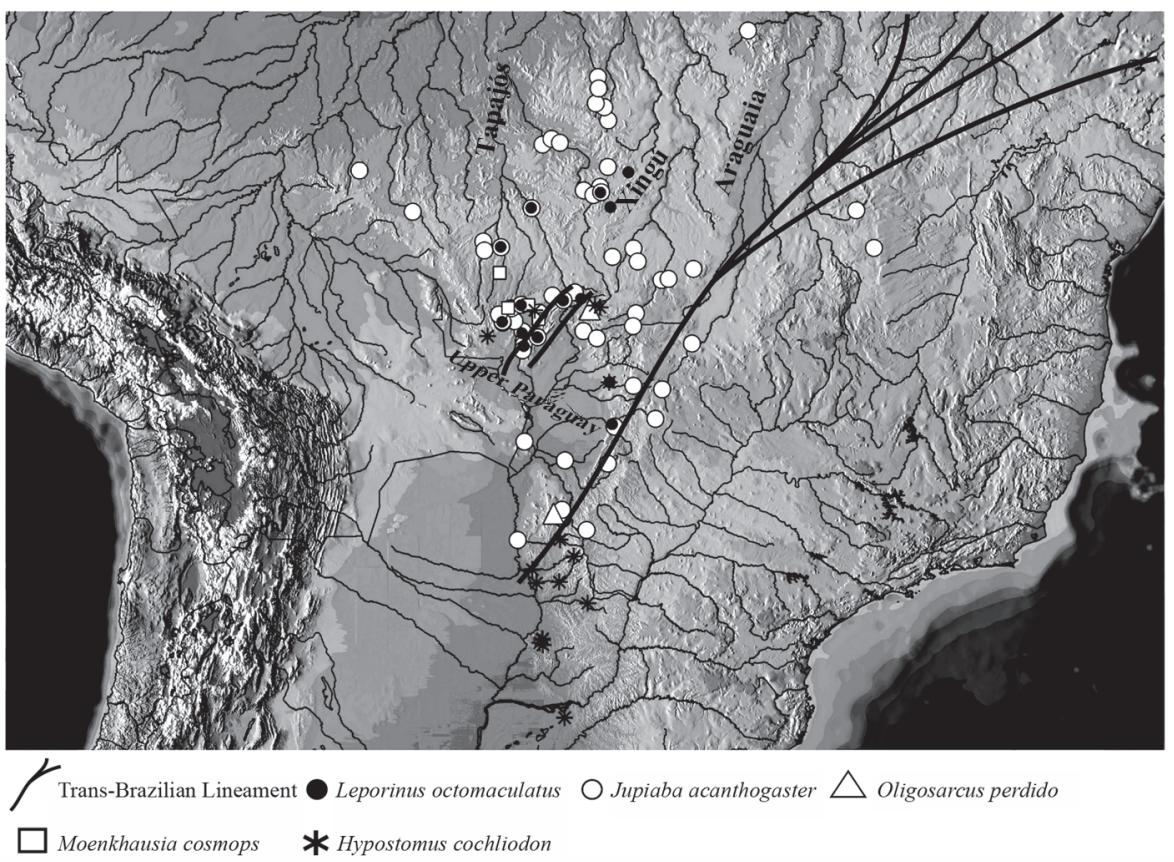

Fig. 1. Map of the upper rio Paraguay basin and adjoining areas showing the distribution of Leporinus octomatulatus, Jubiaba acanthogaster, Oligosarcus perdido, Moenkhausia cosmops, and Hypostomus cochliodon, exemplifying distributional pattern discussed in this paper.

(Zanata, 1997) and the remaining species of the group occurs in the upland amazonian tributaries from central Brazil. Similar distribution is reported for Knodus chapadae, from the upper portion of the upper rio Paraguay and from Tocantins basin (Ferreira, 2007). Our phylogeographyc analysis cared out in J. acanthogaster from 15 localities (Figs. 2-3) corroborate the hypothesis that tectonic origin of the upper rio Paraguay basin correspond to the most recent vicariant event in the evolutionary history of the area since samples from the rio Xingu basin are sister-group of a more inclusive clade encompassing the upper rio Tapajós and upper rio Paraguay. Thus, vicariance between the upper rio Paraguay and upper rio Tapajós is the least event in the biogeographic history of the group (Fig. 3).

The mean nucleotide diversity ( $\circlearrowright$ ) was 0.001152 and the mean haplotype diversity (h) was 0.512167 ; values for each locality are shown in Table 2 . The obtained sequences corresponded to 28 haplotypes and any common haplotype was observed in all localities. The haplotype 15 was shared among three localities [rio Angelim, rio Paraguai (Corumbá) e rio Paraguai (Serra das Araras)], being the most frequent. The haplotypes 4-5, 6-7-8, 9-10-11-12-13-25, 16-27 and 19-20-21 were exclusive from a single locality: rio Salobro, ribeirão dos Veados, rio Culuene, rio Angelim, and rio Aricá-mirim, respectively.

Analysis of Molecular Variance (AMOVA) considering the three main groups identified (upper rio Xingu, upper rio Paraguay and upper rio Tapajós) showed that the variation are greater among the groups than within each group (Table 3). The values of pair-to-pair analysis of the FST shown the occurrence of a strong and significant division among localities $(\mathrm{p}<0.05)$, with values ranging from $-0,03659$ a 1,000 (data not shown). The values of pair-to-pair analysis of the FST considering the three groups (upper rio Xingu, upper rio Paraguay and upper rio Tapajós) also shown the occurrence of a strong and significant difference ( $<<0.05$ ), ranging from 0.73615 to 0.97518 (Table 4 ).

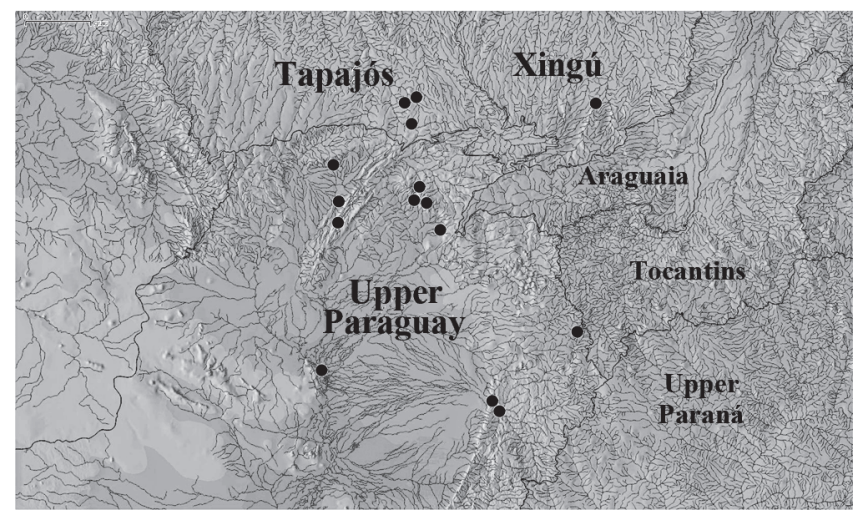

Fig. 2. Distribution of sampled localities for Jupiaba acanthogaster in the upper rio Paraguay, rio Tapajós and rio Xingú basins. The drainages of the rio Tocantins, rio Araguaia and upper rio Paraná are also illustrated. Drainage boundaries delimited by a continuous black line. 


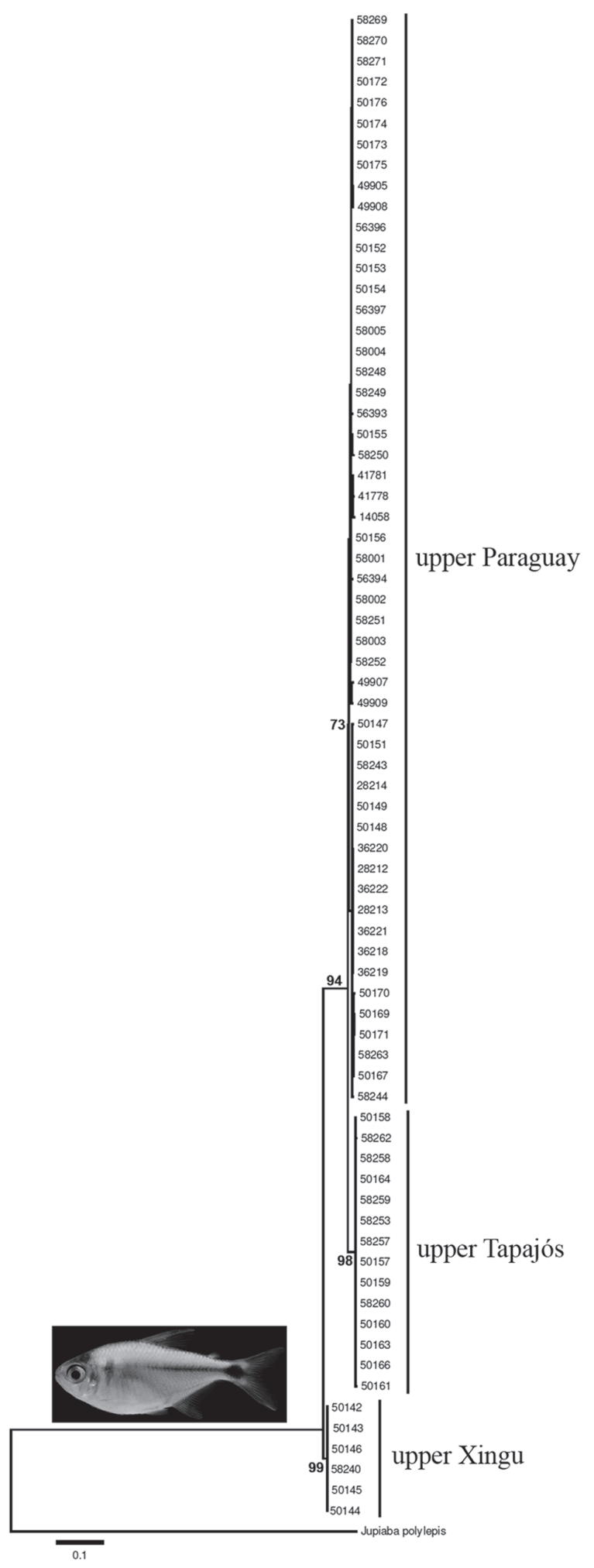

Fig. 3. Phylogenetic tree showing relationships among major lineages of Jupiaba acanthogaster from the upper rio Paraguay, upper rio Tapajós and upper rio Xingu, obtained by a maximum likelihood partitioned analysis. Numbers at each of the main nodes represents percentage of bootstrap support obtained by maximum parsimony analysis (1000 bootstrap pseudoreplicates).
Table 2. Local populations statistics: $\mathrm{n}=$ sample size, $\mathrm{N}=$ number of haplotypes, $\mathrm{h}=$ haplotype diversity, $\partial=$ nucleotide diversity.

\begin{tabular}{ccccc}
\hline Localities & $\mathrm{n}$ & $\mathrm{N}$ & $\mathrm{h}$ & $\pi$ \\
\hline 1 & 6 & 6 & 1.000 & 0.002940 \\
2 & 1 & 1 & 1.000 & 0.000000 \\
3 & 3 & 2 & 0.6667 & 0.001043 \\
4 & 5 & 1 & 0.000 & 0.000000 \\
5 & 2 & 2 & 1.000 & 0.001565 \\
6 & 4 & 3 & 0.8333 & 0.005477 \\
7 & 6 & 3 & 0.6000 & 0.001043 \\
8 & 10 & 3 & 0.3778 & 0.001182 \\
9 & 5 & 3 & 0.8000 & 0.001565 \\
10 & 8 & 1 & 0.000 & 0.000 \\
11 & 4 & 3 & 0.8333 & 0.001565 \\
12 & 5 & 1 & 0.000 & 0.000 \\
13 & 7 & 2 & 0.2857 & 0.000447 \\
14 & 7 & 2 & 0.2857 & 0.000447 \\
\hline
\end{tabular}

The haplotype network (Fig. 4) confirmed the presence of three groups (upper rio Xingu, upper rio Paraguay and upper rio Tapajós), which are separated by 26 (rio Xingu $\mathrm{x}$ rio Paraguay), 38 (rio Xingu $x$ rio Tapajós) and 13 (rio Paraguay $x$ rio Tapajós) mutational steps. Localities within each group have related haplotypes, some even shared, corroborating the degree of relationship among them.

\section{Discussion}

The distributional pattern presented by the above mentioned taxa provide evidences for a relatively recent shared history and disjunction between the upper rio Paraguay and adjoining upland drainage basins. This distribution fits perfectly with the expected effects of the tectonic origin of a giant graben (the Pantanal Wetland) in the area of an ancient Precambrian shield (the Brazilian shield). This has captured to the depression neighboring basins, and limited distribution of strict rheophilic taxa to the depression's periphery, where such habitat persists (Fig. 1).

Additionally, some of the species mentioned above are all included in Amazonian species groups or genera. Leporinus octomaculatus, for example, seems to be closely related to a

Table 3. Analysis of molecular variance (AMOVA) testing for partitioning of genetic variation among populations, grouped according to localities of Jupiaba acanthogaster.

\begin{tabular}{lcccc}
\hline \multicolumn{1}{c}{ Source of variation } & $\begin{array}{c}\text { Degree of } \\
\text { freedom }\end{array}$ & $\begin{array}{c}\text { Sum of } \\
\text { squares }\end{array}$ & Variance & $\begin{array}{c}\% \\
\text { total }\end{array}$ \\
\hline Among groups & 2 & 264.429 & $7.552 \mathrm{Va}$ & 75.36 \\
Among populations within groups & 11 & 117.631 & $2.107 \mathrm{Vb}$ & 21.02 \\
Within populations & 59 & 21.364 & $0.362 \mathrm{Vc}$ & 3.61 \\
Total & 72 & 403.425 & 1.002 .056 & \\
\hline
\end{tabular}


Table 4. Genetic differentiation (Fst) between group pairs. Significance level $\mathrm{p}<0.05$ in 1000 permutations. *significative results.

\begin{tabular}{lccc}
\hline \multicolumn{1}{c}{ Groups } & $\begin{array}{c}\text { upper rio } \\
\text { Xingu }\end{array}$ & $\begin{array}{c}\text { upper rio } \\
\text { Paraguay }\end{array}$ & $\begin{array}{c}\text { upper rio } \\
\text { Tapajós }\end{array}$ \\
\hline upper rio Xingu & 0.00000 & & \\
upper rio Paraguay & $0.84056^{*}$ & 0.00000 & \\
upper rio Tapajós & $0.97518^{*}$ & $0.73615^{*}$ & 0.00000 \\
\hline
\end{tabular}

subset of amazonian species, including Leporinus reticulatus Britski \& Garavello, 1993 (from rios Arinos and Tapajós basin), and Leporinus guttatus Birindelli \& Britski, 2009 (from the rio Xingu river basin) (Birindelli \& Britski, 2009). Jupiaba is a natural group (Zanata, 1997) which includes only amazonian taxa (Lima et al., 2003), as well as the species of the Hypostomus cochliodon group (Armbruster, 2003).

The origin of the Pantanal Wetland is related to tectonic reactivations of Precambrian faults along the Trans-brazilian lineament approximately 2.5 MY ago (Soares et al., 1998; Assine, 2004). This is part of a set of tectonically imposed landscapes along the Andean foreland (see introduction) and illustrates the close causal association between global tectonics not only in global distributional patterns of the biota, but also at a regional and even local scale.

The idea of a close historical relationship between the upper rio Paraguay and adjacent Amazonian basins is not new. Carvalho \& Albert (2011) provided a detailed discussion of this subject, depicting ideas from earlier studies of the nineteenth and twentieth centuries. These authors also provided additional examples of species shared between the rios Paraguay and Amazon basins. However, Carvalho \& Albert (2011) did not provide a causal distinction between fishes that are restricted to headwaters/upland habitat and those widespread in lowland habitats of both rios Paraguay and Amazon basins. As discussed by Lima \& Ribeiro (2011), processes driving distribution of freshwater fishes through time are very distinct between upland and lowland portions of drainage basins in South America. Lowland species tend to present widespread distribution in both rios Paraguay and Amazon basins, not because those basins are connected today, but because basins divide below $250 \mathrm{~m}$ (a.s.l) are ephemeral through time as a consequence of foreland basins tectonic dynamism, allowing expansion of distribution rages

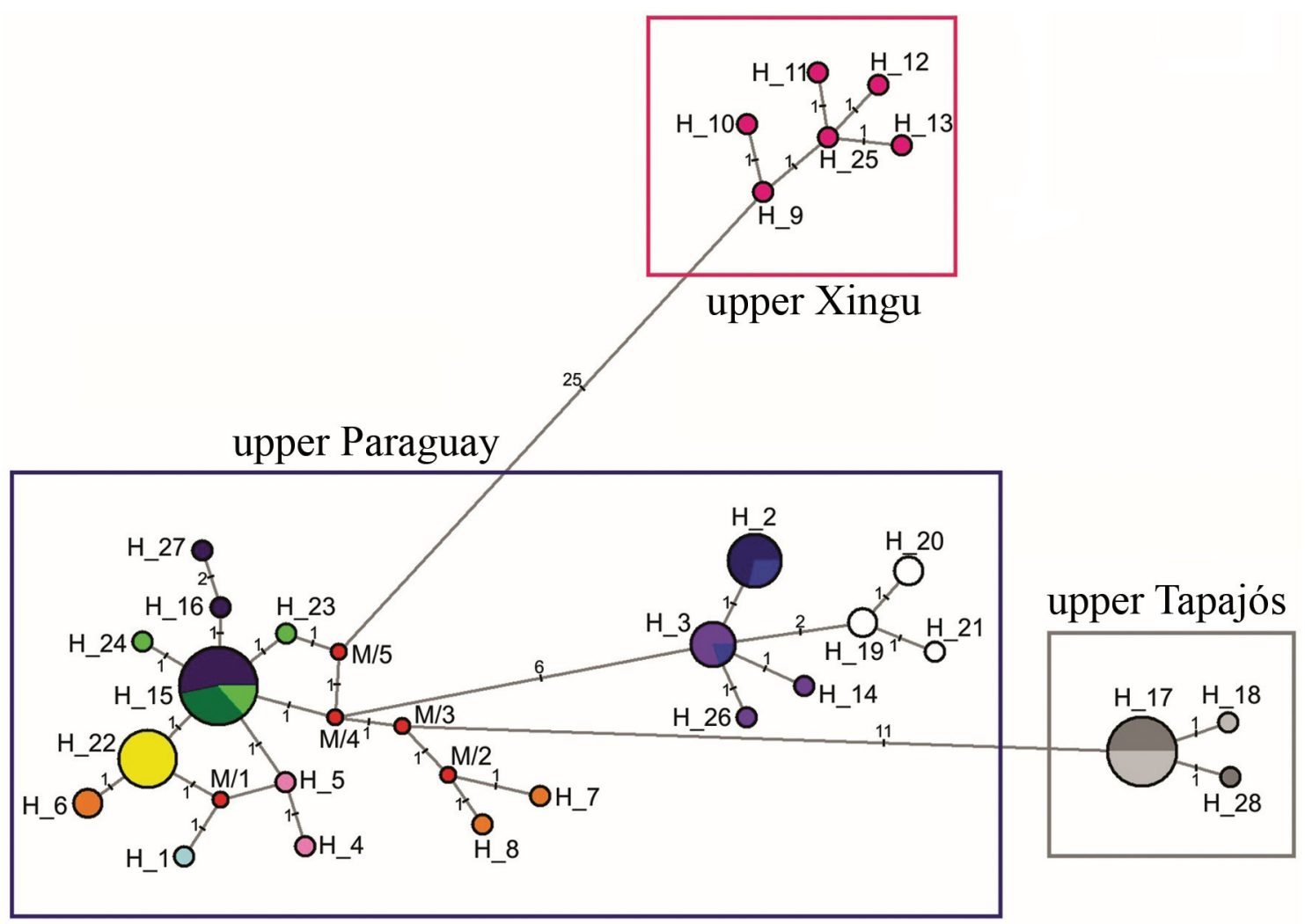

Fig. 4. Haplotype network showing the occurrence of three groups (upper rio Xingu, upper rio Paraguay and upper rio Tapajós). Traces show the number of mutational steps from two adjacent haplotypes. Circle diameters are proportional to the number of individuals, which each haplotype and the colors represent the locality were those haplotypes were found. Upper rio Xingu= Pink (1: dark pink); upper rio Paraguay = Blue (2: light blue; 3: navy blue; 4: dark blue; 5: light pink; 6: orange; 7: light purple; 8: dark purple; 9: white; 10: yellow; 11: light green; 12: dark green); and upper rio Tapajós= Gray (13: light gray and 14: dark gray). 
of several groups. On the other hand, upland taxa are not prone to expand their distributional ranges since upland headwaters are typically isolated by well established divides, running waters and waterfalls. Headwaters captures between adjacent basins (a vicariant event) are the only possibility for strict rheophilic headwaters fishes to become widespread (through range expansion, not by dispersion) in two or more isolate basins (Lima \& Ribeiro, 2011).

The pioneering authors (see Carvalho \& Albert, 2011 for a list of previous authors and ideas on the biogeography of the area) thought the Paraguayan ichthyofauna was formed primarily by migration of taxa from adjacent tributaries of the Amazon Basin and, to a lesser extent, from the La Plata basin and Carvalho \& Albert (2011) suggested this is well corroborated by present knowledge of distribution and phylogenetic data. The map of Fig. 1 does not provide evidence for migration or geodispersion, since all groups are restricted to headwater habitat. This indicates that the distribution of these fishes is a relict pattern, and a consequence of the mega paleogeographic rearrangement caused by subsidence in the upper Paraguay basin. The earlier authors were correct in proposing a close historical relationship between the upper rio Paraguay and Amazon, but, in this case, this was not as a consequence of migration, but of the ancient topographic continuum of the Brazilian Crystalline shield, extending to the southern limit of the upper rio Paraguay basin. This ancient upland was probably drained by Amazonian headwaters. The present-day division has been established very recently, in the Cenozoic (about 2.5 MY ago) and the present day distribution of this set of species was possibly established together with the tectonic origin of the Pantanal Wetland.

\section{Acknowledgments}

Michael Heads and Roberto E. Reis provided a critical review and useful comments over the manuscript. This work was financially supported by FAPEMAT trough undergraduate fellowship to RRSRS (Fapemat process \# 86898/ 2010 ) and research project budget to ACR (process \# 447441/ 2009 and 572844/2008), CNPq (process \# 401818/2010-1 to ACR) and FAPESP (process \# 07/02978-7 to FCTL and 10/ 17009-2 to CO).

\section{Literature Cited}

Albert, J. S. \& R. E. Reis. 2011. Introduction to Neotropical Freshwaters. Pp. 3-19. In: Albert, J. S. \& R. E. Reis (Eds.). Historical Biogeography of Neotropical Freshwater Fishes. Berkeley. University of California Press.

Armbruster, J. 2003. The Species of the Hypostomus cochliodon group (Siluriformes: Loricariidae). Zootaxa, 249: 1-60.

Assine, M. L. 2004. A bacia sedimentar do Pantanal Mato-Grossense. Pp. 61-74. In: Mantesso-Neto, V., A. Bartorelli, C. D. R. Carneiro,. \& B. B. Brito-Neves (Eds.). Geologia do Continente Sul-Americano: Evolução da Obra de Fernando Flávio Marques de Almeida. São Paulo. Editora Beca.
Birindelli, J. L. O. \& H. A. Britski. 2009. New species of the genus Leporinus Agassiz (Characiformes: Anostomidae) from the rio Curuá, rio Xingu basin, Serra do Cachimbo, Brazil, with comments on Leporinus reticulatus. Neotropical Ichthyology, 7: 1-10.

Bizzi, L. A., C. Schobbenhaus, J. H. Gonçalves, F. J. Baars, I. M.Delgado, M. B. Abram, R. L. Neto, G. M. M. Matos \& J. O. S. Santos. 2001. Geology, Tectonics and Mineral Resources of Brazil: Geographic Information System (GIS) and maps at the 1: 2500000 scale. CPRM, Brasília, 4 CD Rom.

Brito, P. M., F. J. Meunier \& M. E. C. Leal. 2007. Origine et diversication de l'ichthyofaune Neotropical: Une revue. Cybium, 31: 139-153.

Britski, H. A. \& J. C. Garavello. 1993. Descrição de duas espécies novas de Leporinus da bacia do Tapajós (Pisces, Characiformes). Comunicações do Museu de Ciências e Tecnologia da PUCRS, Série Zoologia, 6: 29-40.

Carvalho, T. P. \& J. S. Albert. 2011. The Amazon-Paraguay divide. Pp. 193-202. In: Albert, J. S. \& R. E. Reis (Eds.). Historical Biogeography of Neotropical Freshwater Fishes. Berkeley. University of California Press.

DeCelles, P. G. \& K. A. Giles. 1996. Foreland basin systems. Basin Research, 8: 105-123.

Edgar, R. C. 2004. MUSCLE: a multiple sequence alignment method with reduced time and space complexity. BMC Bioinformatics, 5: 113.

Excoffier, L. \& S. Schneider. 2005. Arlequin ver. 3.0: An integrated software package for population genetics data analysis. Evolution Bioinformatics, 1: 47-50.

Excoffier, L., P. E. Smouse \& J. M. Quattro. 1992. Analysis of molecular variance inferred from metric distances among DNA haplotypes: application to human mitochondrial DNA restriction data. Genetics, 131: 479-491.

Fairhead, J. D. \& S. Maus. 2003. CHAMP satellite and terrestrial magnetic data help define the tectonic model for South America and resolve the lingering problem of the pre-break-up fit of the South Atlantic Ocean. The Leading Edge, 2003: 779-783.

Felsenstein J. 1985. Confidence limits on phylogenies: an approach using the bootstrap. Evolution, 39:783-791.

Ferreira, K. M. 2007. Análise filogenética e revisão taxonômica do gênero Knodus Eigenmann, 1911 (Characiformes: Characidae). Unpublished Ph.D. Dissertation, Universidade de São Paulo, Ribeirão Preto, 549p.

Hearn, P. Jr., T. Here, P. Schruben, D. Sherrill, C. LaMar \& P. Tsushima. 2000. Global GIS Database: Digital Atlas of Central and South America. U.S. Geological Survey, Digital Data Series DDS-62-A.

Lima, F. C. T. \& A. C. Ribeiro. 2011. Continental-scale tectonic controls of biogeography and ecology. Pp. 145-164. In: Albert, J. S. \& R. E. Reis (Eds.). Historical Biogeography of Neotropical Freshwater Fishes. Berkeley. University of California Press.

Lima, F. C. T., H. A. Britiski \& F. A. Machado. 2007. A new Moenkhausia (Characiformes: Characidae) from central Brazil, with comments on the area relationship between the upper rio Tapajós and upper rio Paraguai systems. Aqua, 13: 45-54.

Lima, F. C. T., L. R. Malabarba, P. A. Buckup, J. F. Pezzi da Silva, R. P. Vari, A. Harold, R. Benine, O. T. Oyakawa, C. S. Pavanelli, N. A. Menezes, C. A. S. Lucena, M. C. S. L. Malabarba, Z. M. S. Lucena, R. E. Reis, F. Langeani, L. Casatti, V. A. Bertaco, C. Moreira \& P. H. F. Lucinda. 2003. Genera incertae sedis in Characidae. Pp. 106-169. In: Reis, R. E., S. O. Kullander \& C. 
J. Ferraris (Eds.). Check List of the Freshwater Fishes of South and Central America. Porto Alegre, Edipucrs.

Lujan, N. K. \& J. W. Armbuster. 2011. The Guiana Shield. Pp. 211224 In: Albert, J. S. \& R. E. Reis (Eds.). Historical Biogeography of Neotropical Freshwater Fishes. Berkeley. University of California Press.

Menezes, N. A., A. C. Ribeiro, S. H. Weitzman \& R. A. Torres. 2008. Biogeography of Glandulocaudinae (Teleostei: Characiformes: Characidae) revisited: Phylogenetic patterns, historical geology and genetic connectivity. Zootaxa, 1726: 3348.

Menezes, N. A., S. H. Weitzman \& J. R. Burns. 2003. A systematic review of Planaltina (Teleostei: Characiformes: Characidae: Glandulocaudinae: Diapomini) with a description of two new species from the upper rio Paraná, Brazil. Proceedings of the Biological Society of Washington, 116: 557-600.

Miller, M. A., W. Pfeiffer \& T. Schwartz. 2010. "Creating the CIPRES Science Gateway for inference of large phylogenetic trees". Proceedings of the Gateway Computing Environments Workshop (GCE): 1-8.

Nogueira, C., P. A. Buckup, N. A. Menezes, O. T. Oyakawa, T. P. Kasecker, M. B. R. Neto \& J. M. C. Silva. 2010. RestrictedRange Fishes and the Conservation of Brazilian Freshwaters. Plos ONE 5(6):e11390. doi:10.1371/journal.pone.0011390.

Pereira, L. H. G., M. F. Pazian, R. Hanner, F. Foresti \& C. Oliveira. 2011. DNA barconding reveals hidden diversity in the Neotropical freshwater fish Piabina argentea (Characiformes: Characidae) from the Upper Paraná Basin of Brazil. Mitochondrial DNA, 22: 87-96.

Ribeiro, A. C. 2007. Filogenia e biogeografia do gênero Oligosarcus Günther, 1864 (Ostariophysi; Characidae). Unpublished Ph.D. Dissertation, Universidade Estadual Paulista "Júlio de Mesquita Filho", Botucatu, 137p.

Ribeiro, A. C., Cavallaro, M. R. \& O. Froehlich. 2007. Oligosarcus perdido (Characiformes, Characidae), a new species of freshwater fish from Serra da Bodoquena, upper Rio Paraguai basin, Brazil. Zootaxa, 1560: 43-53.

Riccomini, C. \& M. Assumpção. 1999. Quaternary tectonics in Brazil. Episodes, 22: 221-225.

Riccomini, C., L. G. Sant'Anna \& A. L. Ferrari. 2004. Evolução geológica do rift continental do sudeste do Brasil. Pp. 383-405. In: Mantesso-Neto, V., Bartorelli, A., Carneiro, C. D. R. \& B. B. Brito-Neves (Eds.). Geologia do Continente Sul-Americano: Evolução da Obra de Fernando Flávio Marques de Almeida. São Paulo. Editora Beca.
Rice. W. R. 1989. Analyzing tables of statistical tests. Evolution, 43: 223-225.

Schaefer, S. A. 1998. Conict and resolution: Impact of new taxa on phylogenetic studies of the Neotropical cascudinhos (Siluroidei: Loricariidae). Pp. 375-417. In: Malabarba, L. R., R. E. Reis, R. P. Vari, Z. M. S. Lucena \& C. A. S. Lucena (Eds.). Phylogeny and Classification of Neotropical Fishes. Porto Alegre, Edipucrs.

Soares, P. C., M. L. Assine \& L. Rabelo. 1998. The Pantanal Basin: Recent tectonics, relationships to the Transbrasiliano Lineament. Anais IX Simpósio Brasileiro de Sensoriamento Remoto, 459469. Santos: INPE.

Stamatakis, A., P. Hoover \& J. Rougemont. 2008. A rapid bootstrap algorithm for the RAxML web servers. Systematic Biology, 57: 758-771.

Swofford, D. L. 2003. PAUP*: Phylogenetic analysis using parsimony (and other methods). Version 4. Massachusetts: Sinauer Associates, 2003.

Tamura, K. \& M. Nei 1993. Estimation of the number of nucleotide substitutions in the control region of mitochondrial DNA in humans and chimpanzees. Molecular Biology and Evolution, 10: 512-526.

Tamura K., D. Peterson, N. Peterson, G. Stecher, M. Nei \& S. Kumar. 2011. MEGA5: Molecular Evolutionary Genetics Analysis using Maximum Likelihood, Evolutionary Distance, and Maximum Parsimony Methods. Molecular Biology and Evolution, 10: 2731-2739.

Uba, C. E., C. Heubeck \& C. Hulka. 2006. Evolution of the late Cenozoic Chaco foreland basin, Southern Bolivia. Basin Research, 18: 145-170.

Ward, R. D., T. S. Zemlak, B. H. Innes, P. R. Last \& P. D. N. Hebert. 2005. DNA barcoding Australia's fish species. Philosophical Transactions of the Royal Society Biological Sciences, 360: 1847-1857.

Zanata, A. M. 1997. Jupiaba, um novo gênero de Tetragonopterinae com osso pélvico em forma de espinho (Characidae, Characiformes). Iheringia, série Zoologia, 83:99-136.

Submitted September 8, 2012 Accepted April 20, 2013 by Marcelo Britto Published June 28, 2013 